DOI: $10.17805 /$ trudy.2016.1.10

\title{
ВСЕМИРНЫЙ ГОД ШЕКСПИРА
}

\author{
H. В. Захаров \\ (Московский гуманитарный университет)
}

Аннотация: В статье анонсируются мероприятия, которые пройдут в Великобритании и России в связи с 400-летием годовщины памяти У. Шекспира в 2016 г. Отмечаются причины непреходящей популярности британского драматурга XVI-XVII в.

Ключевые слова: Шекспир; Год языка и литературы Великобритании; мероприятия; анонс; юбилей

\section{THE GLOBAL YEAR OF SHAKESPEARE}

\author{
N. V. Zakharov \\ (Moscow University for the Humanities)
}

\begin{abstract}
The article looks at the commemorative events which will take place in the United Kingdom and Russia in 2016 - the year of the 400th anniversary of Shakespeare's death, with a special focus on the reasons for the undying popularity of the English playwright of the 16th and 17th centuries.

Keywords: Shakespeare; UK-Russia Year of language and literature; events; announcement; anniversary
\end{abstract}

23 апреля 2016 г. весь мир готовится отметить 400-ю годовщину памяти великого британского драматурга Уильяма Шекспира. Многочисленные мемориальные мероприятия пройдут по всему свету, не останется в стороне от торжеств и Россия. 2016 год был объявлен у нас в стране Годом языка и литературы Великобритании и посвящен памяти Шекспира.

Для Великобритании поминовение гения стало государственным делом. 5 января 2016 г. в канун Богоявления («Двенадцатую ночь») премьерминистр Дэвид Кэмерон дал старт глобальной программе мероприятий «Shakespeare Lives», которая охватит более 70 стран мира. В частности, он заявил: «Эта дата - не просто повод почтить память одного из величайших драматургов всех времен. Это возможность отдать дань силе воздействия этого человека, который, используя его собственное описание Юлия Цезаря, «как колосс осеняет тесные пределы мира» (Празднование 
жизни и наследия ..., 2016: Электр. ресурс).

Представляется не случайным, что в качестве важнейших элементов значения творческого наследия Шекспира Кэмерон выделил «воспитание и обучение»: «...вклад “Королевской шекспировской компании” (RSC), шекспировского театра "Глобус" и усилия таких новаторских благотворительных организаций как “Школьный фестиваль Шекспира” доказывают, что изучение и исполнение пьес Шекспира развивает грамотность и уверенность в себе, повышает внимание к образовательному процессу» (там же).

Так, Британский совет запустил сразу несколько образовательных и культурных программ, которые пройдут по всему миру. 11 января 2016 г. при поддержке Британского совета и при участии фонда «Дом-музей Шекспира» (Shakespeare Birthplace Trust) стартовал бесплатный онлайн-курс «Изучение английского языка: Шекспир» (Exploring English: Shakespeare). Авторский курс Энтони Косгроува (Anthony Cosgrove) посвящен жизни и творчеству Уильяма Шекспира. На него записалось более 17000 человек из более 100 стран.

«Годовщина памяти Уильяма Шекспира будет отмечаться по всему миру, однако нигде это не будет проходить с таким размахом и вниманием, как в России, где Шекспир, оказавший огромное влияние на творчество русских писателей, сам стал практически “русским” драматургом», - отметил директор Британского Совета в России Майкл Бёрд (Michael Bird).

В 2016 г. продолжит свою работу проект TheatreHD, в рамках которого в 50 городах России, Украины и Казахстана покажут популярные постановки Королевского национального театра, шекспировского театра «Глобус», центра «Барбикан», Метрополитен Опера, Большого театра и др.

23 февраля в родном городе драматурга открыт памятник «Молодой Уильям Шекспир», выполненный в натуральную величину американским скульптором Лоренсом Холофсенером (Lawrence Holofcener). K 400-летней годовщине смерти драматурга известный иллюстратор книг из Стаурбриджа Джефри Тристрам (Geoffrey Tristram) написал портрет «Ожившего Шекспира» (2016). Как пообещал специальный представитель Президента РФ по международному культурному сотрудничеству Михаил Швыдкой, во второй половине 2016 г. в Москве объявят конкурс на создание памятника Шекспиру. В Москве памятника всемирно известному драматургу нет, проект создадут молодые российские скульпторы.

В апреле в Москве откроется выставка «От Елизаветы до Виктории. Английский портрет из собрания Национальной портретной галереи, Лондон». В Государственную Третьяковскую галерею из лондонской Национальной портретной галереи привезут, пожалуй, одно из самых известных изображений Шекспира - «Чандосовский портрет», который датируется приблизительно 1610 годом и приписывается кисти Джона 
Тейлора (ок. 1585-1651); считается, что на нем изображен «смуглый» Уильям Шекспир.

В апреле на Филевской линии московского метрополитена будет ходить тематический поезд, посвященный творчеству Шекспира и его персонажам. Ожидается, что приобщиться к пьесам английского драматурга смогут также пассажиры метро в Санкт-Петербурге, Казани и Екатеринбурге. Выставка, посвященная Шекспиру, откроется в аэропорту Домодедово. Весной пройдут конкурсы для переводчиков британской литературы и олимпиады для школьников. Британский совет при поддержке Министерства образования и науки РФ планирует организовать «Шекспириаду», Всероссийскую школьную олимпиаду для российских школьников на лучшее знание шекспировского наследия. Олимпиада рассчитана на учеников 1-11 классов и начнётся в марте с урока по Шекспиру, в ней примут участие 150000 школьников и 40000 учителей Главным событием Года станет большой летний фестиваль Shakespeare Lives, на котором в одном из парков Москвы декораторы и флористы воссоздадут атмосферу шекспировской Англии.

Осенью в Ясной Поляне будет организован профессиональный семинар российских и британских литературоведов, переводчиков, критиков, журналистов, которые соберутся для обсуждения проблем современной британской литературы. В конце октября 2016 г. в 30 городах России пройдет XVII фестиваль «Новое британское кино». Зрителей ждет специальная тематическая программа фильмов, снятых по мотивам пьес Шекспира. В ноябре на московской книжной ярмарке Non/fiction пройдет масштабная образовательная программа с участием известных писателей из Великобритании.

Исследователи творчества Шекспира соберутся 23-26 марта 2016 г. в Новом Орлеане (Луизиана, США), где состоится 44-й ежегодный съезд Шекспировской ассоциации Америки (The Shakespeare Association's 44nd Annual Meeting, SAA). В рамках цифровой выставки (Digital Exhibits) российские ученые представят шекспировские интернет проекты МосГУ ("Russian Shakespeare Expands into Global Shakespeares: Collaborative Visualization Projects”). 31 июля - 6 августа 2016 г. в Стратфорде-на-Эйвоне и Лондоне будет проходить Х Всемирный шекспировский конгресс: «Создавая и воссоздавая Шекспира» (10th World Shakespeare Congress 2016: Creating and Re-creating Shakespeare). Конгресс станет самым масштабным научным шекспировским событием года. Среди множества предлагаемых семинаров и секций особый интерес для отечественных исследователей творчества британского драматурга должен представить семинар «Шекспир и Центральная / Восточная Европа: тогда и сейчас» (Shakespeare and Central/Eastern Europe: Then and Now). 
В течение всего года продолжит свою работу Международный научный семинар «Шекспир в междисциплинарных гуманитарных исследованиях» (International Scientific Seminar "Shakespeare in Interdisciplinary Humanities Research”), а в сентябре в двадцать шестой раз соберется крупнейшая шекспировская конференция в России - «Шекспировские чтения 2016: 400 лет бессмертия поэта» (Москва, 26-29 сентября 2016 г.). Конференция проводится Шекспировской комиссией при Научном совете «История мировой культуры» Российской академии наук и Московским гуманитарным университетом при участии Государственного института искусствознания (ГИИ), Российского университета театрального искусства - ГИТИС.

В чем же секрет непреходящей популярности драматурга? Как и Пушкин для русской культуры, Шекспир сыграл главнейшую роль в появлении современного литературного английского языка. По подсчетам the Shakespeare Birthplace Trust, Шекспир изобрел 1,000 новых слов. Подсчеты других исследователей насчитывают около 3,000 новых слов и выражений. Но сколько бы ни насчитывал в количественном значении его словарь - 15,000 или 29,000 (глоссарий Shakespeare's Words профессора Дэвида Кристала (David Crystal) содержит около 50,000 записей), главное тут качество владения поэтическим языком, способность создавать яркие художественные образы, умение заставлять нас сопереживать его персонажам. И тут равных Шекспиру нет, а английский стал языком межнационального общения.

Тайна всегда окружала личность Шекспира, но в его биографии не больше белых пятен, нежели в судьбе любого его современника, за исключением, пожалуй, членов королевской семьи и прочих знатных особ. Из метрических книг нам известно, что Уильям Шекспир был крещен 26 апреля 1564 г. в Церкви Святой Троицы в городе Стратфорде-на-Эйвоне. Обычай крестить мальчиков на третий день после их рождения позволяет установить наиболее вероятную дату его рождения, т. е. 23 апреля - день памяти покровителя Англии святого Георгия. В семье было 8 детей, из них трое умерли еще во младенчестве. Детская смертность была обычным делом в тюдоровские времена, сам Уильям пережил эпидемию чумы в первый год своей жизни и потом еще не однажды в Лондоне. Большая семья проживала в доме на Хэнли-Стрит, позже известном как «Старое место» (Old Place).

По ремеслу его отец был перчаточником, успешным предпринимателем, продававшим шерсть, был членом городского совета, в 1568 году он был избран бейлифом, стал городским головой. Похоже, что Шекспир рано приобщился к театральному искусству. Любая труппа, желавшая дать представление в городе, должна была сначала предстать перед се- 
мьей председателя городской корпорации. По разным подсчетам юный Шекспир мог быть свидетелем более 20 таких гастролей в Стратфорде. С 6-7 лет он бесплатно обучался в королевской грамматической школе Эдуарда VI (открыта в 1553). Обычно изучалось богословие и риторика, но главными предметами в ней были языки - латынь и древнегреческий. Тут Шекспир мог познакомиться с произведениями древних авторов (Плавт, Овидий), с античной мифологией и ее героями, которые позже заняли такое значительное место в его творчестве. Школу он оставил в 15 лет, вероятно из-за начавшихся проблем в семье. В 1576 г. Джон Шекспир перестал посещать заседания городского совета, а в 1586 г. он был снят с должности олдермена.

В 1582 г. 18-летний Шекспир женился на Энн Хетеуэй, девушке старше его на 8 лет. Спустя 6 месяцев она рожает ему старшую дочь Сьюзен (крещена 23 мая 1583 г.), а в 1585 г. близнецов - дочь Джудит и сына Гамнета (крещены 2 февраля). Вскоре Шекспир оставляет жену и детей в Стратфорде, а сам переезжает в Лондон, но продолжает регулярно посещать родные места, вероятно, чтобы проведать близких и привезти домой деньги. Сын Гамнет прожил только 11 лет и умер от болезни в августе 1596 года.

К 1592 г. он уже известный писатель, в дневнике антрепренёра Филипа Хенслоу есть упоминание постановки исторической хроники «Генрих VI» в театре «Роза». Тогда же году умирающий Роберт Грин обрушился на Шекспира с резкой критикой, назвав его «потрясателем сцены» (shakescene), «выскочкой», «вороной, щеголяющей в наших перьях»). Таким образом, Грин предупреждал ведущих драматургов - «университетских умов» (Кристофер Марло, Томас Нэш) о появлении на лондонских подмостках опасного конкурента.

В Лондоне он начал работать в первом театральном здании, которое так просто и называлось «Театр», а с 1593 г. переходит в труппу «Слуги лорда-камергера» с прославленным актером Джеймсом Барбеджем. С 1594 года Шекспир стал её совладельцем, а в 1597 г. труппа перебирается в театр «Занавес». Судя по всему, в амплуа актера он имел небольшие роли, например, Тень отца в «Гамлете», основное время уделяя сочинению пьес.

Предприимчивая натура заставляла его искать дополнительные доходы. В 1599 г. он вошел в число пайщиков театра «Глобус», выстроенного сыновьями Джеймса Барбеджа Ричардом и Катбертом Барбеджами. Новый театр открылся постановкой трагедии Шекспира «Юлий Цезарь». К этому времени его финансовые дела идут в гору, отныне он состоятельный человек, приобретает недвижимость - земельные участки, дома на родине и в Лондоне. В 1597 году покупает для семьи в Стратфорде один из самых больших домов «Новое место» (New Place), в 1596-1598 гг. попа- 
дает в «Записку о зерне и солоде» своего будущего свата Ричарда Куини, где речь шла о 70 семей, которые в неурожайные годы скрывали излишки зерна. В 1599 г. к радости своего отца Шекспир получает дворянское звание - джентльмен. 8 сентября 1601 г. в церкви св. Троицы состоялись похороны Джона Шекспира, джентльмена из Стратфорда-на-Эйвона.

Расцвет творчества Шекспира приходится на первое десятилетие XVII века. Похоже, что после 1603 г. Шекспир перестает выступать на сцене и целиком посвящает себя драматургическому творчеству. Так, в издании трудов Бена Джонсона 1616 года можно встретить имя Шекспира в списках актёров, игравших в пьесах «У всякого свои причуды» (1598) и «Падение Сеяна» (1603).

В 1613 г. после пожара, уничтожившего театр «Глобус», Шекспир возвратился из Лондона в Стратфорд, наведываясь время от времени в столицу по делам.

Шекспир умер 23 апреля 1616 г. и был похоронен в родном Стратфорде, в церкви Троицы. Своей жене Энн он завещал «вторую по качеству кровать», лучшую, по-видимому, должны были унаследовать новые хозяева Нью-Плейс - Сьюзанн Шекспир и ее муж Джон Холл. Этот факт, три подписи Шекспира, сделанные неверной (дрожащей) рукой, породили множество спекуляций.

Литературная репутация Шекспира, как одного из ведущих английских драматургов и поэтов была признана его современниками. В 1623 г. Джон Хеминг и Генри Конделл, актеры труппы Барбеджа, подготовили собрание сочинений барда, более известное как «Первое фолио» (1623), т. е. книга большого формата в $1 / 2$ листа. На титульном листе стояло полное название - «Комедии, хроники и трагедии У. Шекспира». В издание были включены (без соблюдения хронологического порядка) 36 пьес (теперь к ним добавляют еще две пьесы - «Два знатных родича» и «Перикл»). В предисловии выдающийся драматург и друг поэта Бенджамин Джонсон (ок. 11.06.1573 - 6.08.1637) написал о Шекспире, что он «не принадлежит только своему веку - он на все времена».

Развитие «шекспировской индустрии» шагнуло значительно дальше популярных изданий произведений Шекспира, создания культа вокруг различных театральных, кинематографических и телевизионных постановок его произведений, передач о жизни и творчестве драматурга. Она все более приобретает черты коммерческой эксплуатации образа как самого Барда, так и созданных им героев, использование их изображений на сувенирах (футболках, кружках, брелоках, магнитах и т. д.).

Местом паломничества поклонников драматурга со всего мира давно стал Стратфорд-на-Эйвоне. При численности населения в 23,6 тыс. человек город ежегодно принимает до 5 млн человек, желающих посетить родные места Шекспира. Городская казна ежегодно пополняется миллио- 
нами фунтов стерлингов от «бардотуризма».

Развитие новых информационных технологий придало «шекспировской индустрии» новые черты, особенно в части представления информации в Интернете. Массовые открытые онлайн-курсы (МОOK) как образовательная инновационная технология охватывают необычайно большое число слушателей курсов, посвященных изучению творчества Шекспира. Например, только один курс «Шекспир: в книге и на сцене» собрал на платформе EdX более 20000 слушателей. Еще большее количество студентов, профессиональных деятелей театра и даже коллегшекспироведов привлекли внимание шекспировские онлайн-курсы на платформе FutureLearn.

В связи с бумом, связанным с расцветом шекспировских МООКов среди преподавателей, шекспироведов, которые участвуют в создании подобных курсов, можно говорить об особой форме существования «шекспиросферы» в современной образовательной среде. К интеграции новых технологий и образовательных программ способна не любая архаика, ценная лишь тем, что пережила века, но прежде всего та, которая образует культурную константу, сохраняет духовную, нравственную и эстетическую ценность для новых поколений.

Именно в этом - загадка и разгадка нашего современника Шекспира.

\section{СПИСОК ЛИТЕРАТУРЫ}

Празднование жизни и наследия Уильяма Шекспира в 2016 году (2016) [Электронный ресурс] // Gov.Uk. 6 января. URL: https://www.gov. uk/government/world-location-news/celebrating-the-life-and-legacy-ofshakespeare-in-2016.ru (дата обращения: 11.01.2016).

Дата поступления: 12.02.2016 г.

Захаров Николай Владимирович - кандидат филологических наук, доктор философии (PhD), директор Центра теории и истории культуры Института фундаментальных и прикладных исследований Московского гуманитарного университета, ученый секретарь Шекспировской комиссии Российской академии наук. Адрес: 111395 , Россия, г. Москва, ул. Юности, д. 5, корп. 6. Тел.: +7 (499) 374-75-95. Эл. адрес: nikoltine@yandex.ru

Zakharov Nikolay Vladimirovich, Candidate of Philology, PhD, Director, Center for Theory and History of Culture, Institute of Fundamental and Applied Studies, Moscow University for the Humanities; Academic Secretary, Shakespeare Committee, Russian Academy of Sciences. Postal address: Bldg. 6, 5 Yunosti St., 111395 Moscow, Russian Federation. Tel. +7 (499) 374-75-95. E-mail: nikoltine@yandex.ru 